\title{
Modeling of High School Educational Environment Based on Synergetic Approach
}

\author{
Synergetic ideas in pedagogical modeling
}

\author{
Victor Kureychik \\ CADS Department, ICTIS \\ Southern Federal University \\ Taganrog, Russia \\ kur@tgn.sfedu.ru
}

\author{
Veronika Pisarenko \\ Foreign Languages Department \\ Southern Federal University \\ Taganrog, Russia \\ vero19671993@gmail.com
}

\begin{abstract}
The article is devoted to synergetics consideration as a base of a new approach to the designing of a high school educational environment. Various approaches to the educational environment definition were analyzed. Application of seven main principles of synergetics in pedagogical science was analysed and on their basis the principles of designing of the high school educational environment were formulated. The model of the educational environment which can be used as a basis for designing of corresponding training system by the teacher of higher school was offered. The model of a teacher's personality was analyzed.
\end{abstract}

Keywords-synergetics, modern education system, methodology of modern science, humanitarian sciences

\section{INTRODUCTION}

The modern stage of science development is characterized by the processes of scientific differentiation and integration, synthesis of scientific knowledge, transferring research methods from one area to another. These features of modern scientific knowledge promote the search for new ways of education sphere development. The global objective of education is defined as the formation, improvement and development of the multidimensional creative personality who perceives the world holistically and is able to be active in professional and social spheres.

The current post-non-classical stage of science development is characterized by the real understanding of the extreme complexity of the studied objects, as well as the deep limitations of our intellectual and technical assets. The term post-non-classical science does not mean the refusal of the modern non-classical worldview. It represents the following revolutionary transformation of science, its new phase.

The formation of post-non-classical science is associated with synergetic ideas primarily. Synergetics is not a distinct scientific discipline, and integrative scientific field or research program [1, 2], having a holistic look. Diverse research areas and directions found common conceptual ground in synergistics. With the appearance and popularization of synergetics, the ideas of non-linear development and selforganization have attracted scientists to consider the existing systems of different nature on the base of universal methodology. It has been predominant since [3].
The appearance of synergetic methods and conceptions in education is logical. It reflects a new stage in the development of synergistic knowledge - the stage of synergetic methodology formation. At this stage, it is necessary not only to systematize the accumulated methodological and theoretical developments, methods of their use in various spheres of knowledge for the solution of research tasks, but also to develop mechanisms of learning these techniques, in other words, to provide not only production, but also adequate reproduction of synergetic knowledge $[1,2,3]$.

The use of synergetic principles in the pedagogical research and development of the modern higher school educational environment will ensure its functioning at a new level that meets modern scientific picture of the world.

\section{THE GENESIS OF THE CONCEPT "EDUCATIONAL ENVIRONMENT" IN PEDAGOGICS}

The problem of creation of the higher school educational environment is not new. It was developed by B.N. Bogatyr, V.V. Gusev, G.V. Karpova, M.V. Klarina, N.F. Maslova, M.S. Chvanova and many other scientists [4-10].

The process of informatization of all areas of scientific life explains the widespread use of relevant terminology in scientific research. The term educational environment has come from computer science. Changes in the world scientific picture, namely, the adoption of the universal evolutionism concept in modern science, which is based on evolution as a biological phenomenon, determined the popularity of biological terms, one of which is environment.

Analysis of the literature on the development and implementation of educational environment [4-17] showed that, first, the creation of the educational environment can be considered as an approach in the organization of innovative training. Secondly, the concept of educational environment has multiple levels: educational environment of a university, of a technical university, a subject (discipline) educational environment etc. Thirdly, it is necessary to ascertain a diversity in consideration of the concept of educational environment, its components, content etc. by various authors. 
For example, V. Gusev [8] considers this approach as the design and implementation of educational environment based on the integration of professionally oriented and socially developing educational technologies that enhance cognitive activity of students in the university.

In this case, we speak about the use of the educational environment in order to control the process of the future specialist identity and professionalism formation.

M. S. Chvanova has proposed another approach, based on ideas of technocracy [9]. She introduces the concept of a professionally oriented educational environment. It is considered, firstly, as a set of tools and technologies for the collection, storage, transmission, processing and distribution of educational and professionally oriented information; secondly, as a set of conditions conducting to the emergence and development of information interaction between teacher, learners and tools of information and communication technologies. "Technocratic" approach to the problem means that the author does not consider media, information, and communication technologies in the framework of a unified educational system. We mean the use of software, hardware and technical means in the educational process, not the technology.

Another approach has been suggested in [10] (M. J. Vilensky, P.I. Obraztsov, and A.I. Uman). In accordance with this approach, you need to create at the University a "special professionally-oriented education environment, integrating into the set of inherent information and technological components of educational process informatization". The authors mean a special environment, filled with professional subject-oriented content that meets the requirements of training specific skills in the university.

Dictionary on pedagogy defines environment as "the totality of conditions surrounding a person and interacting with him as organism and personality" [11].

Dictionary of modern general education considers the educational environment as 1) a set of educational factors based on the principles of environment; 2) view of the environment, factors which have an educational nature [12].

D.V. Chernilevskiy notes that educational environment represents an expanding sphere of life of a growing person, a student, including an increasing richness of its culturemediated relations with the world. Educational environment teaches to extract knowledge from his or her own activities, observations and perceptions, to reveal the vital importance of the objects being studied [13].

V.A. Yasvin defines the educational environment as a system of influences and conditions for personality formation in accordance with a given sample, as well as opportunities for its development contained in the social, spatial, and subject environment [14-17].

Analysis of these definitions and many others [5-7] has allowed us to propose our own definition of the educational environment in modern information space as the sphere of activity defined by the educational interests of the person and by its needs in information exchange with the environment.

\section{SyNERGETICS IDEAS IN EDUCATION}

\section{A. Features of the Synergetic Approach in the Educational Sphere}

The essence of the synergetic approach is that a complex structural system, consisting of elements being in interactions with each other and having a huge number of freedom degrees can be described by a small number of essential types of motion (order parameter). All the other kinds of motion are "subordinates" (principle of subordination) and can be expressed accurately through the order parameter. Complex behavior of systems can be described using a hierarchy of simplified models, including a small number of the most essential degrees of freedom [19].

In accordance with a synergetic paradigm, educational environment of modern higher school has bifurcation (critical) points. In these points, old structures are destroyed. It means the emergence of new opportunities for system transition to a new quality. Educational environment has the property of linearity, i.e., the multiplicity and unpredictability of the transition of a system from one state to another. The education system is unstable. It is in a state of disequilibrium and fluctuation. It is open for development, etc. The attractors are values that are more meaningful for the system's development. The process of meaning formation should be arranged in a manner that inside this organization semantic self-organization took place. The formation of the semantic foundations of a student is based on synergetic laws. Self-organization takes place, if a system is in the state of non-equilibrium. This state occurs if substance or energy are "pumped" through the system. In education system, this energy is information. In synergetics we speak about the areas of attraction, where the phase trajectories will tend to come to a particular attractor - a special region that draws a trajectory of a further development $[1,2,19-21]$. As a result, an unstable equilibrium is minimal, and the reduction to this level is an indicator of the system's development. The system's development continues and results in the emergence of new non-equilibrium state of the system.

If we observe this process in a personality's development the state of personality's non-equilibrium means the point where a person having a certain level of knowledge makes decisions about the ways (directions) of the further development.

The process of evolution is characterized by a change of the conditional states of order and chaos in the system. Between them there are intermediate phases of transition to chaos (destruction of structure) and out of chaos (self-organization). Only one, stable, the longest time phase refers to the genesis, homeostasis of the system. The other three are associated with the chaos and treat the formation or crisis. It is necessary to take into account the arbitrariness of the partitioning, since in every order there is an element of chaos and, on the contrary, in chaos there is always order items, the issue is the extent of their mixing.

In education environment modeling, we have used seven basic principles of synergetics: two principles of Being, and five principles of Formation. They have been proposed in [1921, 33]. Two principles of Being (homeostaticity, hierarchy), 
characterize the "order" phase, the stable operation of the system, its rigid ontology, transparency and ease of description. Five principles of Formation (non-linearity, instability, openness, dynamic hierarchy, observability) represent the phase of system transformation, upgrading, its passing sequentially through all stages of the death of an old order, chaos testing of alternatives and the birth of a new order.

The principle of Homeostasis means that the system keeps its program functioning in some framework that allows it to move towards the purpose of its existence. For education systems, for example, it is manifested in using the basic laws of an individual and society development, taking into account of psychological features of trainees in the organization of the education process.

The principle of Hierarchy means the composite nature of the higher to the lower. In language, for example, the hierarchy is implemented in the presence of words, phrases, texts. In the world of ideas, the hierarchy is expressed in the existence of opinions, attitudes, ideologies, paradigms, etc. In pedagogy, for example, we can observe the hierarchy of educational levels, educational institutions, the hierarchy of competencies in personality structure, etc.

Non-linearity means the acceptance of multiple ways of development. In humanitarian sense, it means that the result is disproportionate to efforts, inadequate to efforts. The game is not worth it. The whole is not the sum of its parts, as the sum is not the same quality components, etc. In education system, it is a content of education changing constantly. It is inconsistent with the system of competences of students now, which forces the teacher to change the trajectory of education constantly. There is a nonlinearity, of both process and outcome. The outcome of the educational process is significantly different from the intentions of its participants. In addition, the nonlinearity of the pedagogical process is the ability to define an individual trajectory of education, the pace of a student to achieve different levels of education, select the type of educational institutions, disciplines and teachers, forms and methods of training individual tools and techniques, creative tasks.

Instability. In the point of instability (bifurcation), the system becomes open to other levels of existence, to influences. The ever-increasing educational information space displays pedagogical system and pedagogical process of stable equilibrium.

The openness means the impossibility of neglecting the interaction of the system with its environment. In pedagogics, the principle of openness is a necessary condition for the pedagogical process self-organizing, when the existing methodologies do not deny, but complement each other. This makes it possible to use a variety of pedagogical approaches, methods and techniques of teaching, the complexity and polyphony of the cognitive processes seamlessly. A pedagogical system can be regarded as open, because it is undergoing the process of exchange of information (knowledge) between teacher and students (feedback) and focused extraction of information. New goals, methods and means of teaching appear constantly. When considering the process of formation of student's personality as a process of self-organization and self-development we should keep in mind contacts and its interaction with the external environment (group mates, parents, teachers, etc.). For example, the teacher assumes the flow of information and energy, encourage a future specialist for self-organization and self-development, formation of his personality. This interaction from the position of synergetics should possess a number of features. A student may be considered as a disordered, chaotic system that has an infinite number of degrees of freedom. Upon contact of this system with the external environment (in our case with the teacher and not only him), when it absorbs information and energy from another system there is a reduction in the number of degrees of freedom. This is the essence of self-organization. Hence, the influence of the teacher is a part of the optimal, reasonable limits on the freedom of choice and is of a managing nature.

Dynamic hierarchy represents the basic principle in the system bifurcation point. It means the presence of stages of birth, growth and death, the emergence of a new quality system.

Observability means the limitations and relativity of our perceptions about the system in the final experiment. Pedagogical processes are characterized by their uniqueness. In the study of natural phenomena (physics or chemistry), the researcher can repeat the experiment using the same materials, while not limiting in time. In pedagogics and all the other education sciences this approach is impossible. During the second study, we have already to deal with other "materials", and over time, the old conditions are never repeated.

All these facts prove that the education processes have properties of non-equilibrium (the dependence of process characteristics from time and space), the nonlinearity (an ambiguous dependence of the teaching performance from other factors) and openness (information exchange between subsystems and the environment).

We can observe other synergistic phenomena in education and pedagogical systems. It proves that synergetic methodology is universal and it helps to study, to understand better social phenomena, and to consider them as a part of general process of development. Let us consider some of them.

The process of self-organization is the spontaneous emergence of relatively stable existence of open nonequilibrium systems, new structures, process or a set of processes in the system contribution to the maintenance of its optimum functioning, promoting self-construction, self-repair and self-transformation of education system. Self-organization in the education system presupposes the existence of a specific interaction between the trainers and trainees that meets the requirements of the development of the pedagogical system and follows from the objective conditions of its self-movement. It allows us to understand the mechanism of pedagogical process development.

Chaos in the education system is present in all its components: the presence of a huge information field for various academic disciplines in which the learner will navigate and build a certain logical structure; the existence of a large number of pedagogical approaches, technologies, methods, 
ways, and receptions of the organization of the educational process. A teacher will navigate there in accordance with academic standards and its own vision of the educational process. There is no single solution and approach to problem situations. It is also the emergence of pedagogical situations of uncertainty; disorganized and spontaneous aspirations of the learner, etc.

The randomness in the education system represents a departure from the rigid curriculum, the emphasis on the importance of improvisation, intuition, ability to change the whole scenario classes because of the seemingly random replica of the student or other "small" events.

The process of qualitative changes happens in the area of bifurcation (branching), where at the bifurcation point, the system selects its new structure of multiple alternatives. This new structure is capable of dissipation, of the entropy production and of the future evolution. Bifurcation in the education system represents alternative ways of the fan of possibilities in the choice of information and technological support of the educational process. It is also the critical moment of uncertainty about the future development of the student, when he is aware of the need for further development; as well as the moment of awareness of the need for further cultural and professional development of teachers arising from dissatisfaction with his activities, problems encountered in teaching practice, etc. The further work with the literature and reflection on the studied problem may lead the teacher to a point of bifurcation, when system sensitivity is exacerbated to the extent that the minimum accidental exposure may cause rapid irreversible process, called "catastrophe" in synergetics. We speak about well-known "butterfly effect", when some random factor (the thought expressed by somebody, an empirical fact given in some article, the result of the pilot study, the scheme given in the book or phrase, dropped by a colleague, etc.) leads to the fact that a variety of previously disparate views are combined into a new well-ordered structure [21].

An attractor in synergetics is understood as a possible relatively stable state, resulting from the evolutionary processes in open nonlinear media. In a pedagogic system, for example, when a teacher passes a bifurcation point his further work is aimed at giving a new socio-cultural frame to his points of scientific views. It means to hone the wording, to find additional arguments, to make links, i.e., to generate a text corresponding to the attractor. However, if a teacher is under the influence of some other random factor at the bifurcation point, the development of his system of scientific views could go in a completely different way. An attractor in a pedagogic system can be a system of competences. Its formation in student's personality can represent a target of the functioning of the entire educational system.

\section{B. Synergetic principles of designing of the educational environment}

Let us formulate the following principles for the design of an educational environment of a higher educational institution in accordance with the synergetic paradigm of human sustenance based on the new logic of the formation of worldview, and on the basis of analysis of scientific literature on the problem of designing and functioning of the education environment:

- The principle of harmonization and humanization resulting from the synergetic principle of openness, when the existing methodologies do not deny, but complement each other; according to this principle formal mathematical language cannot be considered as universal without interaction with the conceptual, spiritual, humanitarian methods. Humanization and liberalization should be a major consideration in the design and functioning of the educational environment.

- The variability principle resulting from the synergetic principle of non-linearity. Education and training of a specialist of a high level is carried out on the multiple and alternative basis. Points of instability are associated with the choice of further trajectory of education. The conflict of styles in the training process leads to the change of trajectory of study. This principle is realized also in the mastery of ways of thinking and abilities.

- The principle of comparative analysis of values systems resulting from openness and instability principles. The development and improvement of the student's personality is performed on the basis of comparison of the student's own system of personal meanings that are accumulated in the culture. The disciplines of a humanitarian cycle have a special potential in this case.

- The principle of non-linearity of interaction: the functioning of the educational environment can be considered effective if it is a nonlinear process of human interaction with the intelligent environment in which the person perceives it to enrich their own inner world and makes it ripe for the multiplication capacity of the environment;

- The principle of openness of the educational environment: the educational environment should be an open system. It means that it consists of subsystems, between which there is a constant exchange of information; it is a subsystem of a system of higher order, and it exchanges information with other its subsystems;

- The principle of plurality: it means the plurality in the process of values and further ways of development selection. The choice usually is determined by semantic importance of the studied realities for the student. The process of training includes a variety of trends, accompanied by natural and managed processes of destruction of old and the emergence of new systems of search and acquisition of new meanings;

- The principle of self-development means that the transition from control to self-government in an education environment must be provided. From development under the influence of external factors to self-development under the influence of internal factors. A teacher provides and supports the flow of information and energy and encourages a future specialist for selforganization and self-development. It contributes to the 
formation of his personality. This interaction from the point of view of synergetics should possess a number of features. The personality of a student can be a disordered, chaotic system, which has infinite number of degrees of freedom. In the contact of this system with the external environment (in our case with the teacher and not only him), when it absorbs information and energy from another system there is a reduction in the number of degrees of freedom, which represents the essence of self-organization;

- The principle of profiling of educational environment: the training of a future specialist is made in the context of future professional activities. It means that all disciplines that are filling the educational environment, providing overall development of an individual, are somehow connected with the future profession;

- The principle of visualization of studies. The current rapid development of mathematical modeling and computational (computers) experiment, computer graphics open the possibility for a new synthesis of video, audio, textual and formalized-mathematical means of transferring scientific information. In this way, we can use the benefits of "left-brain" (logicalconceptual) and "right brain" (visual-figurative) thinking. The ability of productive imagination and creative intuition get new impulses for development by the immersion of a person in a virtual reality simulated by a computer. Due to synergetic ideas, the connection of two complementary ways of understanding the world - understanding through the image and through the number becomes possible;

- The principle of individualization of learning. According to it, we assume the definition of the student as an active subject of knowledge, using the basic laws of development of an individual, society, the reliance on a subjective experience of the student, his personal psychic and psychophysiological features of communicative abilities. This principle follows the synergetic principle of homeostasis, i.e. maintaining the program operation of the system in some framework that allows it to follow its target;

- The principle of taking into consideration all engineering and psychological features of interaction of the system "student - teaching aids - environment". It results in using the last achievements of ergonomics, in studying problems arising in system "man - machine environment", as well as engineering psychology. It means the investigation of the regularities of the information processes of human interaction and technology with the aim of using them in the practice of creation and operation of systems "man-machine". This principle means the environmental reflection considering the implications of the introduction of technical training in the educational environment; ergonomic reflection, exploring the compliance of the technical means and capacity of man; a target reflection to consider technical system as a means of achieving training purposes.
These principles, formulated above, helped to develop an integrated model of the educational environment in a modern technical University.

\section{Modeling of University educational environment on the basis of synergetic principles}

Effective problem solving to improve the educational process in the University associated with the choice of content, media, and learning technologies, involves the representation of objects, subjects and processes for the preparation and formation of future specialists in different systems (educational, pedagogical etc.). The study of these systems to determine their efficiency, suitability, etc., is connected with the creation of their models (mathematical, semantic, verbal, symbolic, and substantive). The model in this case will be considered as a subject, which in some respects has similarities with the analogue, it is a means of describing, explaining, or predicting its behavior. In addition, each of the studied systems can be represented as some number of models (subsystems), the form of which depends on the required depth of knowledge, level of abstraction, forms of material presentation.

Therefore, to justify the essence of the variable of professionally oriented educational environment of the University it is expedient to use the method of pedagogical modeling, which allows considering each of its components in their unity and interaction. The use of models is the formalization of the learning process. Models are ideal objects, the counterparts of real subjects and objects. They record only the foundation of processes and phenomena, freeing them from unnecessary detail and making them available for study.

Taking into account the positions of personality-oriented paradigm, systemic, activity approach, and the methodology of innovative training, discussed above, we represent a variable professionally oriented educational environment as an integrated model. This model consists of five independent, but interrelated and interdependent models: a model of a specialist's personality, a model of a discipline, a model of a learning process, and models of student and teacher's personality (Fig.1). Let us specify that the concept model of personality is used as the most adequate for the representation of people - participants of education process. Here an individual is seen as a social being, formed in a particular system of social relations, in our case - education relations.

Model of a specialist's personality reflects the requirements for fundamental, theoretical, special and practical training, the professional qualities of a future specialist. This model plays a bridging role in education environment, brings together all the other components.

In fact, it is the standard of development of important professional qualities of future specialist, which allows to transform general objectives and content of education in didactic objectives and contents implemented in the curriculum. 


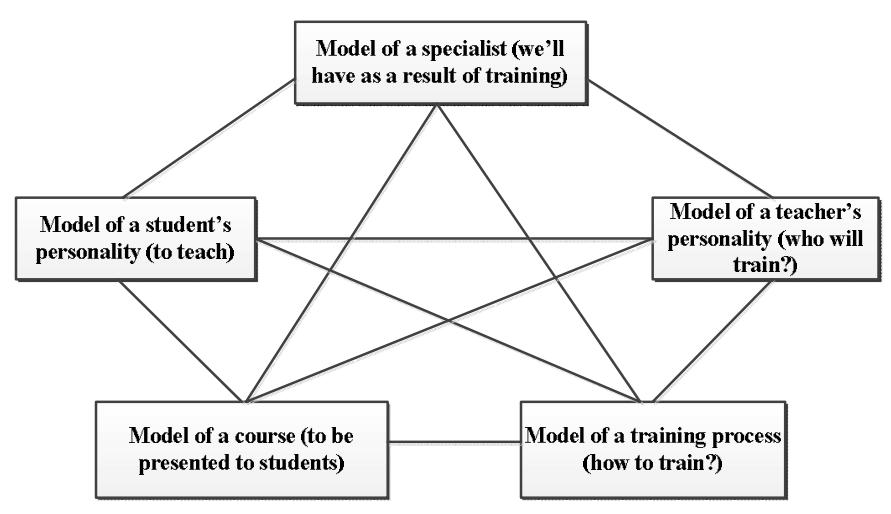

Fig. 1. Integrated model of professionally oriented educational environment

Consequently, the model of a specialist acts as a template for the design and construction of the proper learning and training system. Requirements to a modern specialist are reflected in curricula, programs, teaching materials, methods and means of training.

A general model of a specialist is formed in the process of disclosure and analysis of the abstract and the concrete in the activities of different specialists. The study of theoretical works and empirical analysis of different types of activity allows to allocate the following main function blocks: motivation; goal setting; planning; information; decision-making; the subsystem of professional qualities of a specialist [24, 25].

Changes in society impose new requirements to specialists and the quality of their training. They are formulated as a list of basic competencies. In accordance with the personalityoriented education paradigm in the education standard of the higher educational institutions, it is necessary to provide mechanisms that help to shape spiritual qualities of an individual. Therefore, the objectives of the educational process at the University may include: 1) forming the base of common cultural and professional competences; 2) spiritual and moral development of an individual; 3) the creation of active civic and professional positions; 4) development of communicative and information culture.

In accordance with the objectives, the core competencies of a graduate can be represented by three blocks:

- Cultural competences are formed and developed primarily in the development of disciplines of humanitarian, socio-economic trends and natural sciences;

- Methodological competences are the result of studying of disciplines of a general professional block;

- Professionally oriented competences related to the disciplines of specialization.

The model of a concrete specialist differs in content. Differences could be observed in the models of the same specialist assigned to different levels of education (bachelor, master). These differences can occur in the set of parameters of the expert and the criterion values for individual parameters (different requirements for theoretical and practical training).
The model of the student's personality is a specific set of characteristics of an individual student, who is waited to be a highly qualified specialist to perform the functions of a specialist in a particular field of employment. This model allows a teacher to analyze and consider psychological, physiological and socio-psychological qualities of a student in their teaching activities, level of his preparedness to work with the information resources, level of competence in various disciplines, the training that was carried out in high school, or University, if it is not a first-year student [25].

Model of personality of a teacher (Fig.2) contains the personal qualities of the teacher and his professional competence

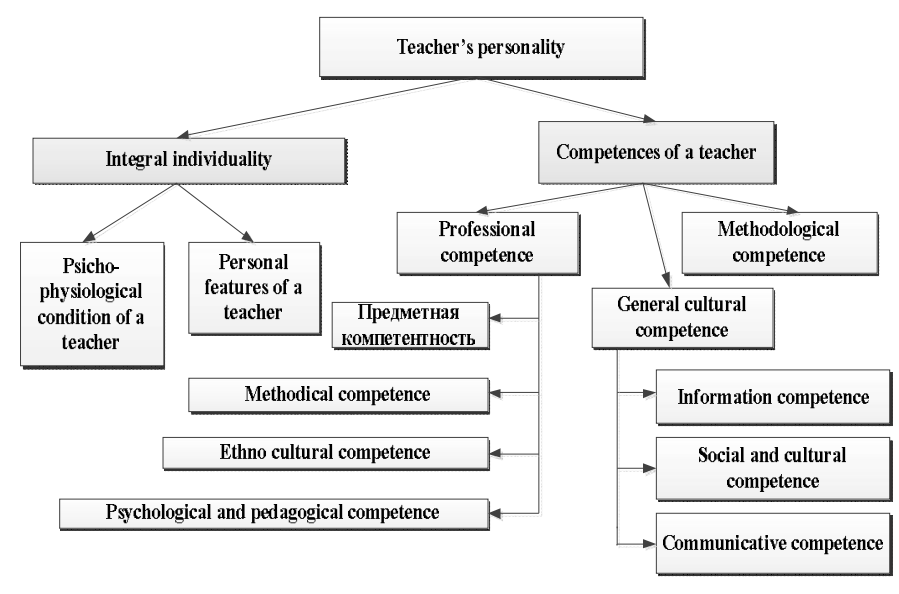

Fig. 2. Model of a teacher personality

required for successful teaching. Personal qualities include professional quality, depth of knowledge of subject area disciplines, the possession of teaching methods with modern approaches, methodologies, methods, techniques and technologies of learning.

The model of the discipline includes learning objectives, features of professionally-oriented system of knowledge and competences, the extent and depth of their formation, information-based and didactic requirements: scientific content, regularity, sequence learning, visualization [18].

The model of the training process reveals the features of implementation of teacher instructional capabilities of technology to learning.

When creating a professionally oriented educational environment for the study of a particular academic discipline the teacher should develop all models progressively in accordance with the requirements of the model of the specialist training which is carried out in this University.

Use of modeling method in the development and study of educational environment allows to represent the object in the totality of all its components. Modeling also allows to trace the connections of the various components.

\section{CONCLUSION}

Modern higher education fulfills a social order for training specialists who will be capable to adapt to social and economic 
changes in their professional activities. In these conditions, education process needs a qualitative change. It has to be oriented to a new specialist formation. A new specialist means not only a high level of professional competences. Professional knowledge and experience are very important. General level of a personality development is much more important. It shows not only a general level of personality's development but also the potential of a personality in society development.

Personality orientation of education requires a search for other grounds for the design of the educational process. The basis for the design of modern educational environment is the totality of knowledge about the patterns (and the factors, conditions, mechanisms) of a personal development. One of the functions of the personality is a continuous search for study and revision of the meaning of her acts and life in general, knowledge of the world and transform herself. The development of personality appears as semiconstrained the individual's internal world, that is self-organization. Therefore, use of the synergetic ideas in the development of educational space is promising and improves the efficiency of training.

Modeling of education environment allows to understand better its essence, to consider the environment's components and their role in education process organization.

\section{ACKNOWLEDGMENT}

This work was supported in part by the Ministry of Education and Science of the Russian Federation "Organization of scientific research" under Grant 2.5537.2017/VU.

\section{REFERENCES}

[1] H. Haken, Ed., "Synergetics," 1973.

[2] H. Haken, "Synergetik," 1990.

[3] V. Stepin, "Theoretical Knowledge," 2005.

[4] "Environment and Education - an Indian Perspective," The Environment and Science and Technology Education, p. 11, 1987.

[5] C. Bauer, "Introduction Environment in Technology and Engineering Education," The Environment and Science and Technology Education, pp. $257-267,1987$.

[6] M. S. Swaminathan, "Education, Environment and Livelihood Security," The Environment and Science and Technology Education, pp. 13-23, 1987.

[7] R.W. Colton, "Education and Environment," Science for Better Environment, pp. 979-984, 1977.

[8] V.V. Gusev, "Upravlenie kachestvom podgotovki voennogo specialista: opyt sistemnogo modelirovaniya". Monografiya. Orel. 1997.

[9] M.S.Chvanova, "Informatizaciya sistemy nepreryvnoj podgotovki specialistov: metodologiya, teoriya, praktika”. - M.-Tambov, 2000.

[10] V.Y.Vilenskij, P.I.Obrazcov, A.I.Uman, "Tekhnologii professional'noorientirovannogo obucheniya $\mathrm{v}$ vysshej shkole": Uchebnoe posobie / Pod red. V.A.Slastenina. - M.: Pedagogicheskoe obshchestvo Rossii, 2004,192 p.

[11] "Slovar'-spravochnik po pedagogike" / Avt. - sost. V.A.Mizherikov; Pod obshch. red. P.I.Pidkasistogo. - M.:TC Sfera, 2004, 448 p.

[12] Z.I.Tyumaseva, E.N.Bogdanov, N.P.Shcherbak, "Slovar'-spravochnik sovremennogo obshchego obrazovaniya: akmeologicheskie, valeologicheskie i ehkologicheskie tajny". - SPb.: Piter, 2004, 464 p.

[13] D.V.Chernilevskij, "Didakticheskie tekhnologii v vysshej shkole": Uchebn. posobie dlya vuzov. M.: YUNITA - DANA, 2002, 437 p.
[14] V.A.Yasvin, "Obrazovatel'naya sreda ot modelirovaniya $\mathrm{k}$ proektirovaniyu". M.: Smysl, 2001, 365 p.

[15] V. A. Yasvin and S. N. Rybinskaya, "Influence of Characteristics of the School Environment for the Academic Achievements of Students," Philosophy. Psychology. Pedagogy, vol. 15, no. 2, pp. 68-72, Apr. 2015.

[16] V. A. Yasvin, "Development of Regional Standard of General Education Social Quality Concept," European Journal of Contemporary Education, vol. 1, no. 1, pp. 82-92, Sep. 2012.

[17] V. Yasvin, M. Rusetskaya, and M. Osadchiy, "Assessment of School and University Environments by High School and College Students," Biomedical and Pharmacology Journal, vol. 8, no. 2, pp. 761-772, Dec. 2015.

[18] V.N.Lozovskij, S.V Lozovskij, "Koncepcii sovremennogo estestvoznaniya": Uchebnoe posobie. 2-e izd., ispr. - SPb.: Izd-vo «Lan'», 2006., $224 \mathrm{p}$.

[19] "Sinergetika". Trudy seminara. Tom 3. Materialy kruglogo stola "Samoorganizaciya i sinergetika: idei, podhody i perspektivy". - M.: Izd-vo MGU. 2000. - 368 p.

[20] "Sinergetika i metody nauki". - SPb.: Nauka, 1998. - 439 p.

[21] "Sinergetika i psihologiya. Teksty". Vypusk 1. "Metodologicheskie voprosy". Pod redakciej I.N.Trofimovoj, V.G.Budanova. - M.: Izd-vo MGSU «Soyuz», 1997. - $361 \mathrm{p}$.

[22] I.V. Abakumova, P.N. Ermakov, I.A. Rudakova, "Smyslocentrizm v pedagogike: novoe ponimanie didakticheskih metodov". - Rostov n/D: Izd-vo Rost. un-ta, 2006. - 256 p.

[23] Y.V. Sharonin, "Sinergetika v upravlenii uchrezhdeniyami obrazovaniya”. Vysshee obrazovanie. - 1999. - №4. - pp. 14-18.

[24] V.M. Kureychik, V.I. Pisarenko, "Sinergeticheskij podhod v innovacionnom obrazovanii”. Otkrytoe obrazovanie. 2007. № 3. -pp.20 $-29$.

[25] V.M. Kurejchik, V.I. Pisarenko "Sinergeticheskie principy v modelirovanii pedagogicheskih sistem". Otkrytoe obrazovanie. 2013. № 6 , pp. $16-24$.

[26] V. Pisarenko and M. Bondarev, "Infographics Use in Teaching Foreign Languages for Specific Purposes," Recent Patents on Computer Science, vol. 9, №. 2, pp. 124-132, Jul. 2016.

[27] V Pisarenko "Informational and technological support of foreign language training in high school," 2015 9th International Conference on Application of Information and Communication Technologies (AICT), Oct. 2015.

[28] V. Pisarenko and Sh. Arsaliev, "Audiovisual technologies for foreign laguages teaching," 2016 IEEE 10th International Conference on Application of Information and Communication Technologies (AICT), Oct. 2016.

[29] V. Pisarenko and G. Krasnoshchekova, "Video in teaching," 2016 IEEE 10th International Conference on Application of Information and Communication Technologies (AICT), Oct. 2016.

[30] Sh. Arsaliev, "New information technologies in ethnopedagogical process," 2015 9th International Conference on Application of Information and Communication Technologies (AICT), Oct. 2015.

[31] Sh. Arsaliev, "Ethnopedagogical Technologies: Best Approaches and Practices," Recent Patents on Computer Science, vol. 9, № 2, pp. 173184, Jul. 2016.

[32] S. Arsaliyev and R. Dendiyeva, "Factors defining need in improvement of quality of moral and aesthetic education of school students," Uchenye zapiski universiteta imeni P.F. Lesgafta, № 107, pp. 07-10, Jan. 2014.

[33] V. Arshinov and V. Budanov, "Cognitive Foundations of Synergetics," PsycEXTRA Dataset. 